28 Resarch Square

\title{
Effects of long-term warming on microbial nutrient limitation of soil aggregates on the Qinghai-Tibet Plateau
}

\section{Wenjing Chen}

Northwest A\&F University

Huakun Zhou

Northwest Institute of Plateau Biology

\section{Leilei Qiao}

Qinghai University

\section{Yuanze Li}

Chinese Academy of Sciences and Ministry of Water Resources

\section{Yang Wu}

Chinese Academy of Sciences and Ministry of Water Resources

\section{Jiaying Zhai}

Chinese Academy of Sciences and Ministry of Water Resources

\section{Guobin Liu}

Chinese Academy of Sciences and Ministry of Water Resources

\section{Sha Xue ( $\nabla$ xuesha100@163.com )}

Institute of Soil and Water Conservation Chinese Academy of Sciences and Ministry of Water Resources:

Chinese Academy of Sciences and Ministry of Water Resources Institute of Soil and Water Conservation

\section{Research Article}

Keywords: Qinghai-Tibet Plateau, Soil aggregate, Enzyme stoichiometry, Nutrient limitation

Posted Date: September 22nd, 2021

DOI: https://doi.org/10.21203/rs.3.rs-604652/v2

License: (9) This work is licensed under a Creative Commons Attribution 4.0 International License. Read Full License 


\section{Abstract \\ Background and aims}

Global warming has increasingly serious impacts on the structure and function of the Tibetan Plateau ecosystem. However, the mechanism by which warming affects the biogeochemical processes, and consequently the microbial nutrient limitation in soil aggregates, is not clear.

\section{Methods}

In the present study, we used open-top chamber experiments to simulate warming in an alpine meadow and an alpine shrubland on the Qinghai-Tibet Plateau, and we measured the $C, N$, and P-acquiring enzyme ( $\beta$-1, 4glucosidase, BG; leucine aminopeptidase, LAP; $\beta$-N-acetylglucosaminidase, NAG; alkali phosphatase, AP) activities and their stoichiometry to understand how warming affects microorganism-limiting mechanisms in soil aggregates.

\section{Results}

The results showed that long-term warming treatment significantly decreased soil organic carbon (SOC) and total nitrogen (TN) concentrations of large macroaggregates (LMGA) and small macroaggregates (SMGA) in alpine meadows, but significantly increased SOC concentration of LMGA in alpine shrubland. The SOC and TN concentrations of alpine meadows increased with the decrease of soil aggregate size and the concentrations in microaggregate (MIGA) were significantly higher than those LMGA. Soil enzyme activity increased with the decrease in aggregate size and was not significantly affected by warming treatment. Enzyme stoichiometry results demonstrated that soil microbes in alpine meadows and shrubland were limited by nutrient $\mathrm{P}$ relative to nitrogen; moreover, the long-term warming treatment aggravated the $\mathrm{P}$ limitation of soil microorganisms in the shrubland, and it had significant differences in LMGA and MIGA. At the same time, the long-term warming treatment had no significant effect on $\mathrm{C}$ limitation in the alpine shrubland and alpine meadows, but soil aggregate size affected the $\mathrm{C}$ limitation patterns of microorganisms and showed the greatest limitations in MIGA.

\section{Conclusions}

The microbial P limitation in shrubland is more sensitive to warming than that in meadow. Soil aggregates mediate the acquisition of $\mathrm{C}$ by microorganisms, and the $\mathrm{C}$ limitation in MIGA is the greatest. By providing a new perspective on this topic, our study increased our understanding of the effects of warming on microbial nutrient utilization and restriction patterns in soil aggregates.

\section{Introduction}


Starting with the Industrial Revolution, greenhouse gas emissions have been causing a continuous increase in global temperatures, and a temperature rise of $2-4.5^{\circ} \mathrm{C}$ has been predicted by the year 2100 (O'Neill et al., 2017; Rogelj et al., 2012). The Qinghai Tibet Plateau possesses the world's highest and largest alpine grasslands, and its fragile ecological environment is highly vulnerable to climate change (Lehnert et al., 2016). Global warming impacts not only the soil environment, including soil temperature and moisture (Brzostek et al., 2012; Nie et al., 2014), but also the length of the growing season (Post et al., 2009) and species composition of plant communities (Saxe et al., 2001). In order to better understand the response of the Tibetan Plateau to future climate change, more mechanism characteristics of ecological structure and function need to be considered.

Soil microorganisms, the driving forces of the biogeochemical cycle and energy flow in ecosystems (Sinsabaugh and Biochemistry, 2010), are very sensitive to changes in the living environment. However, microorganism growth and development are usually limited by nutrient resources (Ekblad and Nordgren, 2002). Changes in external conditions (such as land-use changes, nitrogen deposition, and global warming) often affect the nutrient limitation patterns of microorganisms by changing the state and concentration of soil nutrients (Chen et al., 2018; Chen et al., 2019; Wang et al., 2014). For example, Chen et al., (2018) found that N addition aggravated microbial $\mathrm{C}$ limitation, and Chen et al., (2019) found that cropland conversion alleviated microbial C limitation, which was due to the elevated soil carbon concentration. Previous studies have shown that warming changed the state and stoichiometry of soil $\mathrm{C}, \mathrm{N}$, and $\mathrm{P}$ by regulating the growth of plants and microorganisms in the Tibetan Plateau (Chen et al., 2020; Zhang et al., 2015), which may directly change the nutrient limitation pattern of microorganism.

Soil enzymes play a key role in decomposing organic matter and determining the availability of soil nutrients (Meng et al., 2020). Microorganisms decompose soil organic matter by releasing the C-, N-, and P-acquiring enzymes to meet their corresponding resource demands (Qiao et al., 2019). Previous studies have shown that the soil enzyme activity responses to warming are diverse (Bell et al., 2010; Nie et al., 2013; Zhou et al., 2013), which may be related to the changes of soil available nutrient stoichiometry under warming. Soil enzyme stoichiometry reveals the relative changes in different enzyme activities, and it has been suggested to be an effective indicator to reveal microorganism resource limitation patterns (Moorhead et al., 2013; Sinsabaugh et al., 2009). For example, Zheng et al. (2020) found that short-term warming decreased carbon-degrading enzymes and increased C:P enzyme ratios, as well as proposed that warming decreased microbial C limitation but increased microbial P limitation in the alpine timberline of the eastern Tibetan Plateau. Therefore, we believe that the study of soil enzyme activity and its stoichiometry can better reveal the effect of warming on microbial relative $\mathrm{C}, \mathrm{N}$, and $\mathrm{P}$ limitations in the Qinghai Tibet Plateau.

However, to our knowledge, there is a lack of research on the effects of experimental warming on the relative $\mathrm{C}, \mathrm{N}$, and P limitations of microbial processes at the soil aggregate level in Qinghai Tibet Plateau. Soil aggregates are important factors that affect soil physical and chemical properties (such as soil porosity, soil bulk density, water-holding capacity, and soil erosion resistance), thereby shaping the basic soil physical structure (Deng et al., 2018; Zhu et al., 2017). A stable soil aggregate structure provides microorganisms with a suitable living environment by adjusting the flow of water and oxygen (Six et al., 2004). Previous studies have shown that smaller aggregates have higher soil enzyme activity, stronger physical protection ability, and stronger nutrient limitation (Bailey et al., 2012; Bailey et al., 2013). However, long-term warming may alter the 
physical protection of soil organic matter and affect the availability of substrates to microorganisms, which will affect the potential microbial nutrient limiting mechanism. Liu et al. (2021) suggested that long-term warming reduced the SOC and TN concentrations, substrate availability to microbes, and enzyme activity, especially in macroaggregates. Thus, microbial thermal responses in macroaggregates are more sensitive, which may also be the main way of soil nutrient loss under warming (Wang et al., 2016). The stronger nutrient limitation in microaggregates may also be compensated by the longer turnover time of microbial biomass under long-term warming (Bailey et al., 2012). In summary, soil aggregate size mediates microbial climate change feedbacks, and exploring the impact of climate warming on the nutrient limitation mechanism of soil aggregates in the Qinghai-Tibet Plateau is of great significance for further understanding the response of alpine grassland ecosystems to warming.

In the present study, we investigated the distribution characteristics of soil aggregate nutrients and enzyme activities in an alpine meadow and an alpine shrubland on the Qinghai-Tibet Plateau under a warming treatment, using chemometric knowledge to explore the resource limits of microorganisms at the aggregate level. We hypothesized that (1) long-term warming treatment would reduce soil nutrient concentration and soil enzyme activity, and (2) microbial nutrients limitation would increase and be the strongest in MIGA as a consequence of warming.

\section{Materials And Methods}

\section{Experimental site}

The study site was located at the Haibei Alpine Meadow Ecosystem Research Station (101 $12^{\prime} \mathrm{E}, 37^{\circ} 30^{\prime} \mathrm{N}$, $3200 \mathrm{~m}$ a.s.I.), in the northeastern part of the Qinghai-Tibet Plateau (Fig. 1). The area has a typical continental monsoon-type climate. The summers are short and cool, and the winters are long and cold (Ji et al., 2017; Jiang et al., 2016). The average annual temperature is $-1.7^{\circ} \mathrm{C}$, annual extreme maximum temperature is 27.6 ${ }^{\circ} \mathrm{C}$, annual extreme minimum temperature is $-37.1^{\circ} \mathrm{C}$, and annual precipitation range is $426-860 \mathrm{~mm}, 80 \%$ of which is distributed in the growing season from May to September. The average annual sunshine duration is 2462.7 hours, with $60.1 \%$ total available sunshine (Zhao and Zhou, 1999). The main soil type is Mollic-Cryic Cambisol (Zhao and Zhou, 1999). The dominant species of the alpine meadow and alpine shrubland are Kobresia humilis and Potentilla fruticosa, respectively (Li et al., 2016; Zhao and Zhou, 1999).

\section{Controlled warming experiment}

In 1997, six warmed plots and six control plots were set up within a fenced area of $30 \times 30 \mathrm{~m}^{2}$ in each of the alpine meadow site and the alpine shrubland site. The adjacent warm plots are $2 \mathrm{~m}$ away. The warming plots were covered by open-top chambers (OTCs) to capture solar energy according to the 'International Tundra Experiment' (ITEX) approach (Marion et al., 1997). OTCs are $1 \mathrm{~mm}$ thick fiberglass truncated cones that are tilted $60^{\circ}$ horizontally inward, with a height of $0.40 \mathrm{~m}$, and bottom and top diameter of 1.48 and $1.08 \mathrm{~m}$, respectively (Sun-Lite ${ }^{\circledR}$ HP, Solar Components Corporation, Manchester, $\mathrm{NH}$, USA). The mean daily soil temperature increased (depth of $12 \mathrm{~cm}$ ) by $0.3-1.9^{\circ} \mathrm{C}$ and average soil moisture reduced by $3 \%$ in the OTCs (Zhang et al., 2017). 


\section{Soil sampling and analysis}

Samples of undisturbed soil were taken from warmed plots and control plots on August 10, 2018 by collecting the surface layer $(0-5 \mathrm{~cm})$ of bulk soils in quadruplicate from each plot using a soil core sampler. Since OTCs showed the warming effect at a depth of $0-12 \mathrm{~cm}$ and the warming effect decreases with the depth of the soil layer (Zhang et al., 2017), the surface soil of $0-5 \mathrm{~cm}$ was selected in the sampling. Subsequently, the samples from each plot were mixed to form a composite sample. Litter and debris were removed before sampling. We carefully transported the samples back to the laboratory to avoid damaging the soil physical structure. In all soil samples, we used the 'optimal moisture' method to separate the aggregates (Bach and Hofmockel, 2014; Dorodnikov et al., 2009; Mendes et al., 1999). First, soil samples were placed in a $4^{\circ} \mathrm{C}$ constant-temperature environment to dry until reaching approximately $10 \%$ gravimetric water content. The samples were then gently sorted by hand to below $8 \mathrm{~mm}$ in size and shaken three times for $2 \mathrm{~min}$ using a mechanical shaker to partition the aggregate sizes. Soil samples were then sieved into three grades using stacking sieves (2 and $0.25 \mathrm{~mm})$ : > $2 \mathrm{~mm}$ (large macroaggregates, LMGA), 2-0.25 mm (small macroaggregates, SMGA), and $<0.25 \mathrm{~mm}$ (microaggregates, MIGA) (Nie et al., 2014). A part of each composite soil sample was placed in a refrigerator at $4^{\circ} \mathrm{C}$ for two weeks to determine soil enzyme activity, and the rest was air-dried to measure other physicochemical properties.

\section{Soil physicochemical properties and enzyme analysis}

Soil organic C (SOC) was assayed by dichromate oxidation (Kalembasa et al., 2010). Total N (TN) was assayed using the Kjeldahl method (Bremner and Mulvaney, 1982). Total P (TP) was measured colorimetrically using the ammonium molybdate method (Schade and Levine, 2003).

We determined the activity of $\beta-1,4$-glucosidase (BG), leucine aminopeptidase (LAP), $\beta-N$ acetylglucosaminidase (NAG), and alkaline phosphatase (AP) using a modified version of standard fluorometric techniques (Chen et al., 2020; Wu et al., 2020) (Table 1). In brief, $3 \mathrm{~g}$ soil samples were placed in $125 \mathrm{~mL}$ of Tris buffer ( $50 \mathrm{mM}, \mathrm{pH}=8.0$ ) and homogenized. The samples were placed in a 96-well microplate with eight repeating groups in each column. After the microplate was loaded, it was shaken, mixed well, and placed in a $25^{\circ} \mathrm{C}$ incubator for $0.5,2$, or $4 \mathrm{~h}$. We then used a microplate reader at $365 \mathrm{~nm}$ for excitation and $450 \mathrm{~nm}$ for emission to measure the amount of fluorescence, and enzyme activity was expressed in $\mathrm{nmol} \cdot \mathrm{g}^{-}$ ${ }^{1} \cdot h^{-1}$.

Table 1

Enzyme introduction of this study

\begin{tabular}{|llll|}
\hline Group & Enzyme name & Abbrev & Function \\
\hline C-acquiring enzyme & $\beta-1,4$-glucosidase & BG & Cellulose degradation \\
N-acquiring enzymes & leucine aminopeptidase & LAP & Proteolysis \\
\cline { 2 - 4 } & $\beta-N$-acetylglucosaminidase & NAG & Chitin and peptidoglycan degradation \\
\hline P-acquiring enzyme & alkali phosphatase & AP & Hydrolysis of organic P \\
\hline
\end{tabular}

Data analysis 
SOC, TN, TP, and enzyme activities were analyzed by one-way analysis of variance (ANOVA) to assess the effect of long-term warming treatment on their distribution in soil aggregates. Duncan's tests at $p<0.05$ were performed for multiple comparisons. All statistical analyses were performed using SPSS 20.0 (IBM SPSS, Chicago, IL, USA), and Origin 9.0 (Origin Lab Corporation, Northampton, MA, USA) was used to prepare graphs.

Vector analysis of enzymatic stoichiometry was used to measure resource limitation (Chen et al., 2018; Moorhead et al., 2013). This method is based on the relative levels of $\mathrm{C}, \mathrm{N}$, and P-acquiring enzyme activity to explore the limitations of microbial resources by using the following equations:

$$
\begin{gathered}
\text { VectorL }=\sqrt{(\ln B G / \ln [L A P+N A G])^{2}+(\ln B G / \ln A P)^{2}} \\
\text { VectorA }=\operatorname{Degrees}(A T A N 2((\ln B G / \ln A P),(\ln B G / \ln [N A G+L A P])))
\end{gathered}
$$

Relatively longer vector $L$ indicated greater $C$ limitation; the vector $A<45^{\circ}$ and $>45^{\circ}$ indicated $N$ and $P$ limitation, respectively. When the vector $\mathrm{A}<45^{\circ}$, smaller angle indicates stronger $\mathrm{N}$ limitation of microbial resources. Similarly, when the vector $A>45^{\circ}$, greater angle indicates stronger $P$ limitation of microbial resources.

\section{Results}

\section{SOC, TN, TP, and enzyme activities}

In the alpine meadow, the SOC concentration under the warming treatment was lower than that under the control treatment, and there was a significant difference in LMGA and SMGA between the two treatments (Fig. 2). However, in the alpine shrubland, the SOC concentration under the warming treatment was higher than that under the control treatment, and there was a significant difference in LMGA between the two treatments. In the alpine meadow, the TN concentration under the warming treatment was lower than that under the control treatment, and there was a significant difference in LMGA and SMGA between the two treatments. In the alpine shrubland, there was no significant difference in TN concentration between the warming treatment and the control treatment. In the alpine meadow, the concentration of SOC and TN decreased with the increase in soil aggregate size, and the concentration of MIGA was significantly higher than that of LMGA. In the alpine shrubland, SOC and TN concentrations did not change with the changes in soil aggregate size. TP concentration in both the alpine meadow and alpine shrubland was less affected by the long-term warming treatment.

In most cases, the warming treatment had no significant effect on enzyme activity, except for AP and LAP of MIGA and BG of SMGA in the alpine shrubland (Fig. 3). In the alpine meadow, BG activity was significantly higher in MIGA than in LMGA and SMGA. In the shrubland, BG, NAG, and AP activities in MIGA were significantly higher than those in LMGA and SMGA. BG, LAP, NAG, and AP activities increased as aggregate size decreased and were higher in the alpine meadow than those in the shrubland.

\section{Ecological stoichiometry and indicators of resource limitation}


In the alpine meadow, compared to the control treatment, the long-term warming treatment significantly reduced the C:P ratios of LMGA and SMGA and the N:P ratios of SMGA and MIGA, whereas it had no significant effect on the $\mathrm{C}: \mathrm{N}$ ratios (Table 2). In this habitat, the $\mathrm{C}: \mathrm{P}$ and $\mathrm{N}: \mathrm{P}$ ratios increased as the soil aggregate size decreased, and MIGA size was significantly larger than LMGA size. In the shrubland, compared to the control treatment, the warming treatment significantly increased the soil aggregate $\mathrm{C}: \mathrm{N}$ ratios and the C:P ratios of LMGA and SMGA. The long-term warming treatment had no significant impact on enzyme stoichiometry in the alpine meadow (Table 3 ). The enzymatic C:P and N:P activity ratios were decreased in the alpine shrubland under the warming treatment compared to those under the control treatment, and there were significant differences in LMGA between the warming and control treatment. Soil aggregate size had no significant effect on enzyme stoichiometry in both habitats.

Table 2

Effects of different aggregate size categories on topsoil stoichiometry of the alpine meadow and shrubland under the long-term warming treatment.

\begin{tabular}{|c|c|c|c|c|c|c|c|c|c|}
\hline \multirow{2}{*}{$\begin{array}{l}\text { Warming } \\
\text { treatment }\end{array}$} & \multicolumn{3}{|c|}{ C:N ratio } & \multicolumn{3}{|l|}{ C:P ratio } & \multicolumn{3}{|c|}{$\mathrm{N}: \mathrm{P}$ ratio } \\
\hline & LMGA & SMGA & MIGA & LMGA & SMGA & MIGA & LMGA & SMGA & MIGA \\
\hline W-AM & $\begin{array}{l}10.58 \\
\pm \\
0.18 \mathrm{~b}\end{array}$ & $\begin{array}{l}10.74 \\
\pm \\
0.17 \mathrm{ab}\end{array}$ & $\begin{array}{l}11.17 \\
\pm \\
0.08 a\end{array}$ & $\begin{array}{l}66.13 \\
\pm \\
2.05 \mathrm{Bc}\end{array}$ & $\begin{array}{l}73.12 \pm \\
2.01 \mathrm{Bb}\end{array}$ & $\begin{array}{l}87.35 \\
\pm 1.81 a\end{array}$ & $\begin{array}{l}6.27 \\
\pm \\
0.25 b\end{array}$ & $\begin{array}{l}6.82 \pm \\
0.21 \mathrm{Bb}\end{array}$ & $\begin{array}{l}7.82 \pm \\
0.13 \mathrm{Ba}\end{array}$ \\
\hline CK-AM & $\begin{array}{l}11.08 \\
\pm 0.26\end{array}$ & $\begin{array}{l}10.62 \\
\pm 0.14\end{array}$ & $\begin{array}{l}10.85 \\
\pm 0.16\end{array}$ & $\begin{array}{l}79.81 \\
\pm \\
4.22 \mathrm{Ab}\end{array}$ & $\begin{array}{l}\text { 88.03 } \pm \\
\text { 5.17Aab }\end{array}$ & $\begin{array}{l}93.50 \\
\pm 2.2 \mathrm{a}\end{array}$ & $\begin{array}{l}7.22 \\
\pm \\
0.41 \mathrm{~b}\end{array}$ & $\begin{array}{l}8.30 \pm \\
0.52 A a b\end{array}$ & $\begin{array}{l}8.63 \pm \\
0.24 \mathrm{Aa}\end{array}$ \\
\hline W-AS & $\begin{array}{l}15.95 \\
\pm \\
0.29 \mathrm{Aa}\end{array}$ & $\begin{array}{l}14.1 \pm \\
0.32 \mathrm{Ab}\end{array}$ & $\begin{array}{l}13.17 \\
\pm \\
0.19 \mathrm{Ac}\end{array}$ & $\begin{array}{l}113.06 \\
\pm \\
6.53 \mathrm{~A}\end{array}$ & $\begin{array}{l}114.94 \\
\pm 7.5 \mathrm{~A}\end{array}$ & $\begin{array}{l}103.49 \\
\pm 5.05\end{array}$ & $\begin{array}{l}7.14 \\
\pm 0.55\end{array}$ & $\begin{array}{l}8.16 \pm \\
0.54\end{array}$ & $\begin{array}{l}7.86 \pm \\
0.39\end{array}$ \\
\hline CK-AS & $\begin{array}{l}12.19 \\
\pm 0.7 \mathrm{~B}\end{array}$ & $\begin{array}{l}13.04 \\
\pm 0.2 \mathrm{~B}\end{array}$ & $\begin{array}{l}12.21 \\
\pm 0.3 \mathrm{~B}\end{array}$ & $\begin{array}{l}88.34 \\
\pm 5.5 \mathrm{~B}\end{array}$ & $\begin{array}{l}91.01 \pm \\
7.06 \mathrm{~B}\end{array}$ & $\begin{array}{l}88.68 \\
\pm 6.35\end{array}$ & $\begin{array}{l}7.31 \\
\pm 0.41\end{array}$ & $\begin{array}{l}6.96 \pm \\
0.48\end{array}$ & $\begin{array}{l}7.25 \pm \\
0.44\end{array}$ \\
\hline \multicolumn{10}{|c|}{$\begin{array}{l}\text { Note: W-AM: Warming-alpine meadow; CK-AM: Control-alpine meadow; W-AS: Warming-alpine shrubland; } \\
\text { CK-AS: Control-alpine shrubland. Values are shown as mean } \pm \text { SE. Different uppercase letters indicate } \\
\text { significant differences among different treatments in the same vegetation type and soil aggregate size at } \\
\text { p }<0.05 \text {. Different lowercase letters indicate significant differences among different aggregates size } \\
\text { categories in the same vegetation type and treatment at } p<0.05, n=6 \text {. }\end{array}$} \\
\hline
\end{tabular}


Table 3

Effects of different aggregate size categories on topsoil enzymatic stoichiometry of the alpine meadow and shrubland under the long-term warming treatment.

\begin{tabular}{|c|c|c|c|c|c|c|c|c|c|}
\hline \multirow{2}{*}{$\begin{array}{l}\text { Warming } \\
\text { treatment }\end{array}$} & \multicolumn{3}{|c|}{ InBG: In(NAG + LAP) } & \multicolumn{3}{|c|}{ InBG: InAP } & \multicolumn{3}{|c|}{ In(NAG + LAP): InAP } \\
\hline & LMGA & SMGA & MIGA & LMGA & SMGA & MIGA & LMGA & SMGA & MIGA \\
\hline W-AM & $\begin{array}{l}1.02 \pm \\
0.02\end{array}$ & $\begin{array}{l}1.04 \pm \\
0.02\end{array}$ & $\begin{array}{l}1.03 \pm \\
0.04\end{array}$ & $\begin{array}{l}0.94 \pm \\
0.01\end{array}$ & $\begin{array}{l}0.97 \pm \\
0.02\end{array}$ & $\begin{array}{l}0.96 \pm \\
0.03\end{array}$ & $\begin{array}{l}0.92 \pm \\
0.01\end{array}$ & $\begin{array}{l}0.94 \\
\pm 0.01\end{array}$ & $\begin{array}{l}0.93 \pm \\
0.02\end{array}$ \\
\hline CK-AM & $\begin{array}{l}1.01 \pm \\
0.04\end{array}$ & $\begin{array}{l}1.01 \pm \\
0.04\end{array}$ & $\begin{array}{l}1.02 \pm \\
0.02\end{array}$ & $\begin{array}{l}0.95 \pm \\
0.01\end{array}$ & $\begin{array}{l}0.97 \pm \\
0.01\end{array}$ & $\begin{array}{l}0.97 \pm \\
0.04\end{array}$ & $\begin{array}{l}0.94 \pm \\
0.03\end{array}$ & $\begin{array}{l}0.96 \\
\pm 0.04\end{array}$ & $\begin{array}{l}0.95 \pm \\
0.03\end{array}$ \\
\hline W-AS & $\begin{array}{l}1.00 \pm \\
0.05\end{array}$ & $\begin{array}{l}1.01 \pm \\
0.05\end{array}$ & $\begin{array}{l}1.06 \pm \\
0.06\end{array}$ & $\begin{array}{l}0.90 \pm \\
0.03 \mathrm{Bb}\end{array}$ & $\begin{array}{l}0.93 \pm \\
0.02 \mathrm{Bab}\end{array}$ & $\begin{array}{l}0.95 \pm \\
0.05 a\end{array}$ & $\begin{array}{l}0.91 \pm \\
0.04 \mathrm{~B}\end{array}$ & $\begin{array}{l}0.92 \\
\pm 0.04\end{array}$ & $\begin{array}{l}0.90 \pm \\
0.02 \mathrm{~B}\end{array}$ \\
\hline CK-AS & $\begin{array}{l}1.01 \pm \\
0.03 \mathrm{~b}\end{array}$ & $\begin{array}{l}1.03 \pm \\
0.03 a b\end{array}$ & $\begin{array}{l}1.05 \pm \\
0.03 a\end{array}$ & $\begin{array}{l}0.96 \pm \\
0.04 \mathrm{~A}\end{array}$ & $\begin{array}{l}0.97 \pm \\
0.03 \AA\end{array}$ & $\begin{array}{l}1.00 \pm \\
0.04\end{array}$ & $\begin{array}{l}0.95 \pm \\
0.01 \mathrm{~A}\end{array}$ & $\begin{array}{l}0.94 \\
\pm 0.01\end{array}$ & $\begin{array}{l}0.95 \pm \\
0.02 \mathrm{~A}\end{array}$ \\
\hline \multicolumn{10}{|c|}{$\begin{array}{l}\text { Note: W-AM: Warming-alpine meadow; CK-AM: Control-alpine meadow; W-AS: Warming-alpine shrubland; } \\
\text { CK-AS: Control- alpine shrubland. Values are shown as mean } \pm \text { SE. Different uppercase letters indicate } \\
\text { significant differences among different treatments in the same vegetation type and soil aggregate size at } \\
\text { p<0.05. Different lowercase letters indicate significant differences among different aggregates size } \\
\text { categories in the same vegetation type and treatment at } p<0.05, n=6 \text {. }\end{array}$} \\
\hline
\end{tabular}

In both alpine meadows and shrubland, the warming treatment had no significant effect on the vector $L$, but it decreased with increase in soil aggregate size (Table 4). In the alpine shrubland, the vector L of MIGA was significantly greater than that of LMGA. The mean vector A was greater than $45^{\circ}$ across all observations in the control and treatment groups. The vector $A$ of the alpine meadows and shrubland increased under the longterm warming treatment compared to those under the control treatment, and warming significantly increased vector A of LMGA and MIGA in alpine shrubland. 
Table 4

Effects of different aggregate size categories on topsoil enzymatic stoichiometry of the alpine meadow and shrubland under the long-term warming treatment.

\begin{tabular}{|c|c|c|c|c|c|c|}
\hline \multirow{2}{*}{$\begin{array}{l}\text { Warming } \\
\text { treatment }\end{array}$} & \multicolumn{3}{|c|}{ Vector L } & \multicolumn{3}{|l|}{ Vector A } \\
\hline & LMGA & SMGA & MIGA & LMGA & SMGA & MIGA \\
\hline W-AM & $\begin{array}{l}1.39 \pm \\
0.01\end{array}$ & $1.42 \pm 0.01$ & $\begin{array}{l}1.41 \pm \\
0.02\end{array}$ & $\begin{array}{l}47.24 \pm \\
0.14\end{array}$ & $\begin{array}{l}46.89 \pm \\
0.13\end{array}$ & $47.02 \pm 0.31$ \\
\hline CK-AM & $\begin{array}{l}1.39 \pm \\
0.01\end{array}$ & $1.40 \pm 0.01$ & $\begin{array}{l}1.41 \pm \\
0.01\end{array}$ & $\begin{array}{l}46.76 \pm \\
0.42\end{array}$ & $\begin{array}{l}46.34 \pm \\
0.49\end{array}$ & $46.40 \pm 0.37$ \\
\hline W-AS & $\begin{array}{l}1.35 \pm \\
0.02 b\end{array}$ & $\begin{array}{l}1.37 \pm \\
0.01 a b\end{array}$ & $\begin{array}{l}1.43 \pm \\
0.03 a\end{array}$ & $\begin{array}{l}47.73 \pm \\
0.46 A\end{array}$ & $\begin{array}{l}47.35 \pm \\
0.45\end{array}$ & $\begin{array}{l}48.06 \pm \\
0.21 \mathrm{~A}\end{array}$ \\
\hline CK-AS & $\begin{array}{l}1.39 \pm \\
0.02 b\end{array}$ & $\begin{array}{l}1.42 \pm \\
0.02 \mathrm{ab}\end{array}$ & $\begin{array}{l}1.45 \pm \\
0.02 a\end{array}$ & $\begin{array}{l}46.39 \pm \\
0.16 \mathrm{~B}\end{array}$ & $\begin{array}{l}46.86 \pm \\
0.15\end{array}$ & $\begin{array}{l}46.38 \pm \\
0.23 B\end{array}$ \\
\hline \multicolumn{7}{|c|}{$\begin{array}{l}\text { Note: W-AM: Warming-alpine meadow; CK-AM: Control-alpine meadow; W-AS: Warming-alpine shrubland; } \\
\text { CK-AS: Control -alpine shrubland. Values are shown as mean } \pm \text { SE. Different uppercase letters indicate } \\
\text { significant differences among different treatments in the same vegetation type and soil aggregate size at } \\
\mathrm{p}<0.05 \text {. Different lowercase letters indicate significant differences among different aggregates size } \\
\text { categories in the same vegetation type and treatment at } p<0.05, n=6 \text {. }\end{array}$} \\
\hline
\end{tabular}

\section{Discussion}

\section{Effects of warming treatment on nutrients and enzyme activities in soil aggregates}

Previous studies reported that warming had positive, negative and no effects on the dynamic changes of soil carbon and nitrogen pool (Bai et al., 2013; Dijkstra et al., 2012; Rui et al., 2011; Rustad et al., 2001), and the interaction between temperature and other abiotic factors was the main reason for these different results (Chen et al., 2020; Zhang et al., 2015). Warming changed the storage of soil nutrients by mediating the relationship between nutrient input by litter and nutrient mineralization output (Guan et al., 2018; Wang et al., 2014). In the present study, warming decreased the SOC and TN concentrations in the alpine meadow, which differed significantly in LMGA and SMGA. A previous study showed that a warming treatment increased soil temperature, which improved soil microbial activity and promoted the decomposition and utilization of organic matter, leading to a decrease in SOC and TN (Rustad et al., 2001). Aggregate size fractionation has shown that the nutrient turnover rate in large aggregates is higher than that in small aggregates (Jastrow, 1996; Six et al., 2000). In alpine meadow, the results showed that the concentrations of SOC and TN in LMGA and SMGA were significantly decreased under warming treatment, but warming had no significant effect on them in MIGA. This indicated that the carbon and nitrogen mineralization rates of large aggregates was more sensitive to warming than those of microaggregates. However, in the shrubland, we found that SOC in the warming treatment group was higher than that in the control group, and there was a significant difference in LMGA between the two groups. During sampling, we found warming significantly decreased the evenness index, diversity index and abundance index in alpine shrubland, but increased above-ground biomass (Table s1). It is possible that the warming treatment reduced the soil moisture (Nie et al., 2014), and the strong 
competition with shrubs resulted in the lower abundance of herbaceous plants. The increased aboveground biomass is mainly shrub biomass, and the refractory shrub litter promoted the accumulation of surface soil nutrients. In the present study, as TP was mainly affected by the soil parent material; warming treatment had no significant effect. In the alpine meadow, SOC and TN concentrations decreased as soil aggregate size increased. Compared to LMGA, MIGA may provide better physical protection and has more stable SOC and TN concentrations (Six et al., 2001).

Soil extracellular enzyme activity can reflect the response of microorganisms to their nutrient requirements (Sinsabaugh et al., 2009). Previous studies have shown that long-term warming treatments significantly influence soil temperature and moisture content (Wang and Wu, 2013), which in turn affect the biogeochemical processes of soil microorganisms (Bell et al., 2010). Previous studies showed that the effects of warming on enzyme activity can be positive (Sardans et al., 2008), negative (Zhou et al., 2013), and neutral (Jing et al., 2014; Meng et al., 2020; Wang et al., 2014). Our study showed that warming had no significant effect on enzyme activity, except for AP and LAP activity in MIGA and BG activity in SMGA in the shrubland. This may be attributed to the coordinated change in biotic and abiotic factors, which maintains system balance under warming conditions (Wang et al., 2014). Nie et al. (2014) further found that soil aggregate size distribution mediates the microbial feedback to climate change. Our research showed that enzyme activities increased as aggregate size decreased, which may be a consequence of a higher contribution of fast-growing microorganisms in MIGA than in LMGA (Dorodnikov et al., 2009; Wang et al., 2015). The greater specific surface area of smaller aggregates than that of larger ones facilitates the attachment of microorganisms on their surface (Amato and Ladd, 1992; vanGestel et al., 1996). In addition, smaller pore sizes in MIGA than those in LMGA provide better physical protection for microorganisms, thereby enabling them to stay in the soil for a longer time (Zhang et al., 2013).

\section{Effects of warming treatment on microbial resource limitation}

Some studies have indicated that warming can increase dissolved organic carbon concentration in the soil solution, which in turn decreases the microbial C limitation (Luo et al., 2009). However, our results demonstrated that the warming treatment had no significant effect on microbial $C$ limitation in the alpine meadow and shrubland. This may be because of the balance between microorganism carbon demand and the input of soil organic carbon during the long-term warming treatment. At the same time, enzyme analysis results proved this point, which showed that warming had no significant effect on BG (C-acquiring enzyme) activity, except in SMGA in the shrubland. The vector $L$ decreased with increase in soil aggregate size, and MIGA was significantly higher than LMGA in the alpine shrubland. Soil aggregate structure affects microbial activities as fluxes of water and oxygen (Six et al., 2004), which can affect the accumulation and distribution of soil nutrients (Jastrow et al., 2007). It can also provide physical protection to prevent the rapid decomposition of soil organic carbon, and the level of protection depends on aggregate size (Pulleman and Marinissen, 2004). Jastrow et al. (2007) reported that the protection of SOC by MIGA is greater than the protection of SOC by LMGA, and soil organic matter (SOM) is more recalcitrant in MIGA than in LMGA. Researchers have also found that the water-soluble carbon and active carbon in macroaggregates were significantly higher than those in micro-aggregates (Jha et al., 2012). 
Our results showed that the vector $A$ was greater than $45^{\circ}$, suggesting that microbial $P$ limitation was widespread in the investigated alpine meadow and shrubland. We also found that $\ln B G: \ln A P$ and $\ln (N A G+$ LAP):InAP were slightly below 1.0, which also demonstrated that the $P$ acquisition enzyme activity was relatively higher than the $\mathrm{C}$ and $\mathrm{N}$ acquisition enzyme activities. The analysis of the second national soil survey showed that the available phosphorus content in the Qinghai-Tibet Plateau is generally lower than the national average (Wang et al., 2008). This may be related to the cold climate of the Qinghai-Tibet Plateau and low rates of P-containing primary mineral weathering (Rui et al., 2012). Compared to the control treatment, the long-term warming treatment significantly exacerbated the microbial P limitation in the alpine shrubland, which was indicated by higher vector $A$. It shows that soil microbial $P$ limitation in shrubland is more sensitive to warming treatment. It is possible that warming promoted the absorption of soil phosphorus by plants, which decreased the concentration of soil available phosphorus, and strengthened the competition between plants and microorganisms for phosphorus resources (Gong et al., 2020). Warming can increase the accumulation of $\mathrm{P}$ in plant biomass (Rinnan et al., 2008) and strengthen the P competition between soil microorganisms and vegetation. In addition, we found that the long-term warming treatment intensified resource competition among plants and led to a decrease in herb biomass. Branches and leaves of shrubs are more difficult to decompose than herbs (Brigham et al., 2018), resulting in weakened nutrient cycling and low available $\mathrm{P}$ content.

\section{Conclusions}

In the present study, we investigated the distribution characteristics of nutrients, enzyme activities, and ecological stoichiometry of soil aggregates in an alpine meadow and alpine shrubland, and explored the resource limits of soil aggregate microorganisms on the Qinghai-Tibet Plateau under a long-term warming treatment. The results showed that long-term warming treatment significantly decreased soil organic carbon (SOC) and total nitrogen (TN) concentration of large macroaggregates (LMGA) and small macroaggregates (SMGA) in alpine meadow, but significantly increased SOC concentration of LMGA in alpine shrubland. The SOC and TN concentrations of alpine meadow increased with the decrease of soil aggregate size and the concentrations in microaggregate (MIGA) were significantly higher than those LMGA. Enzyme activity

increased as aggregate size decreased and was not significantly affected by the warming treatment. Enzyme stoichiometry demonstrated that alpine meadows and shrublands on the Qinghai-Tibet Plateau are mainly microbial $P$ limitation relative nitrogen, and the long-term warming treatment exacerbated $P$ limitation, which had significant differences in shrubland. At the same time. The long-term warming treatment had no significant effect on the $C$ limitation in the alpine shrubland and alpine meadow, but the soil aggregate size affected the $C$ limitation patterns of microorganisms, showing strong limitations in MIGA. Our study can be used as a basis for better predictions of the impact of future global warming on the Qinghai-Tibet Plateau ecosystem.

\section{Declarations}

\section{Acknowledgements}

This work was funded by the National Science Foundation of China (31672475) and Qinghai Provincial Key Laboratory of Restoration Ecology in Cold Regions, Northwest Institute of Plateau Biology (2020-KF-04). 


\section{Conflicts of interest}

All the authors declare no conflicts of interest.

\section{References}

1. Amato M, Ladd JN (1992) Decomposition of 14C-labelled glucose and legume material in soils: Properties influencing the accumulation of organic residue $\mathrm{C}$ and microbial biomass $\mathrm{C}$. Soil Biol Biochem 24(5):455-464

2. Bach EM, Hofmockel KS (2014) Soil aggregate isolation method affects measures of intra-aggregate extracellular enzyme activity. Soil Biol Biochem 69:54-62

3. Bai E, Li SL, Xu WH, Li W, Dai WW, Jiang P (2013) A meta-analysis of experimental warming effects on terrestrial nitrogen pools and dynamics. New Phytol 199(2):441-451

4. Bailey VL, Bilskis CL, Fansler SJ, McCue LA, Smith JL, Konopka A (2012) Measurements of microbial community activities in individual soil macroaggregates. Soil Biol Biochem 48:192-195

5. Bailey VL, McCue LA, Fansler SJ, Boyanov MI, DeCarlo F, Kemner KM, Konopka A (2013) Micrometer-scale physical structure and microbial composition of soil macroaggregates. Soil Biol Biochem 65:60-68

6. Bell TH, Klironomos JN, Henry HAL (2010) Seasonal Responses of Extracellular Enzyme Activity and Microbial Biomass to Warming and Nitrogen Addition. Soil Sci Soc Am J 74(3):820-828

7. Bremner JM, Mulvaney C (1982) Nitrogen-total 1. Methods of soil analysis. Part 2. Chemical and microbiological properties 595-624

8. Brigham LM, Esch EH, Kopp CW, Cleland EE (2018) Warming and shrub encroachment decrease decomposition in arid alpine and subalpine ecosystems. Arct Antarct Alp Res 50(1):10

9. Brzostek ER, Blair JM, Dukes JS, Frey SD, Hobbie SE, Melillo JM, Mitchell RJ, Pendall E, Reich PB, Shaver GRJGCB (2012) The effect of experimental warming and precipitation change on proteolytic enzyme activity: positive feedbacks to nitrogen availability are not universal. Glob Change Biol 18(8):2617-2625

10. Chen H, Li DJ, Zhao J, Zhang W, Xiao KC, Wang KL (2018) Nitrogen addition aggravates microbial carbon limitation: Evidence from ecoenzymatic stoichiometry. Geoderma 329:61-64

11. Chen H, Zheng MH, Mao QG, Xiao KC, Wang KL, Li DJ (2019) Cropland conversion changes the status of microbial resource limitation in degraded karst soil. Geoderma 352:197-203

12. Chen W, Zhou H, Wu Y, Wang J, Zhao Z, Li Y, Qiao L, Chen K, Liu G, Xue S (2020) Direct and indirect influences of long-term fertilization on microbial carbon and nitrogen cycles in an alpine grassland. Soil Biology \& Biochemistry, p 149

13. Chen Y, Feng JG, Yuan X, Zhu B (2020) Effects of warming on carbon and nitrogen cycling in alpine grassland ecosystems on the Tibetan Plateau: A meta-analysis. Geoderma 370:10

14. Deng L, Kim DG, Peng CH, Shangguan ZP (2018) Controls of soil and aggregate-associated organic carbon variations following natural vegetation restoration on the Loess Plateau in China. Land Degrad Dev 29(11):3974-3984

15. Dijkstra FA, Pendall E, Morgan JA, Blumenthal DM, Carrillo Y, LeCain DR, Follett RF, Williams DG (2012) Climate change alters stoichiometry of phosphorus and nitrogen in a semiarid grassland. New Phytol 
196(3):807-815

16. Dorodnikov M, Blagodatskaya E, Blagodatsky S, Fangmeier A, Kuzyakov Y (2009) Stimulation of r- vs. Kselected microorganisms by elevated atmospheric $\mathrm{CO} 2$ depends on soil aggregate size. FEMS Microbiol Ecol 69(1):43-52

17. Ekblad A, Nordgren A (2002) Is growth of soil microorganisms in boreal forests limited by carbon or nitrogen availability? Plant Soil 242(1):115-122

18. Gong SW, Zhang T, Guo JX (2020) Warming and nitrogen deposition accelerate soil phosphorus cycling in a temperate meadow ecosystem. Soil Research 58(1):109-115

19. Guan S, An N, Zong N, He YT, Shi P, Zhang JJ, He NP (2018) Climate warming impacts on soil organic carbon fractions and aggregate stability in a Tibetan alpine meadow. Soil Biol Biochem 116:224-236

20. Haines, AJ.I.J.o.E. (2003) Climate change 2001: the scientific basis. Contribution of Working Group 1 to the Third Assessment report of the Intergovernmental Panel on Climate Change [Book review]. 32(2), 321-321

21. Jastrow JD (1996) Soil aggregate formation and the accrual of particulate and mineral-associated organic matter. Soil Biol Biochem 28(4-5):665-676

22. Jastrow JD, Amonette JE, Bailey VL (2007) Mechanisms controlling soil carbon turnover and their potential application for enhancing carbon sequestration. Clim Change 80(1-2):5-23

23. Jha P, Garg N, Lakaria BL, Biswas AK, Rao AS (2012) Soil and residue carbon mineralization as affected by soil aggregate size. Soil Tillage Research 121:57-62

24. Ji SN, Classen AT, Zhang ZH, He JS (2017) Asymmetric winter warming advanced plant phenology to a greater extent than symmetric warming in an alpine meadow. Funct Ecol 31(11):2147-2156

25. Jiang LL, Wang SP, Luo CY, Zhu XX, Kardol P, Zhang ZH, Li YM, Wang CS, Wang YF, Jones DL (2016) Effects of warming and grazing on dissolved organic nitrogen in a Tibetan alpine meadow ecosystem. Soil Tillage Research 158:156-164

26. Jing X, Wang YH, Chung HG, Mi ZR, Wang SP, Zeng H, He JS (2014) No temperature acclimation of soil extracellular enzymes to experimental warming in an alpine grassland ecosystem on the Tibetan Plateau. Biogeochemistry 117(1):39-54

27. Kalembasa SJ, Jenkinson DSAgriculture F (1973) A comparative study of titrimetric and gravimetric methods for the determination of organic carbon in soil. Journal of the ence of Food Agriculture 24(9):1085-1090. J.J.o.t.e.o

28. Lehnert LW, Wesche K, Trachte K, Reudenbach C, Bendix J (2016) Climate variability rather than overstocking causes recent large scale cover changes of Tibetan pastures. Sci Rep 6:8

29. Li H, Zhang F, Li Y, Zhao X, Cao G (2016) Thirty-year variations of above-ground net primary production and precipitation-use efficiency of an alpine meadow in the north-eastern Qinghai-Tibetan Plateau. Grass Forage Sci 71(2):208-218

30. Liu XJA, Frey SD, Melillo JM, DeAngelis KM (2021) Physical protection regulates microbial thermal responses to chronic soil warming. Soil Biology \& Biochemistry, p 159

31. Luo CY, Xu GP, Wang YF, Wang SP, Lin XW, Hu YG, Zhang ZH, Chang XF, Duan JC, Su AL, Zhao XQ (2009) Effects of grazing and experimental warming on DOC concentrations in the soil solution on the Qinghai- 
Tibet plateau. Soil Biol Biochem 41(12):2493-2500

32. Marion GM, Henry GHR, Freckman DW, Johnstone J, Jones G, Jones MH, Levesque E, Molau U, Molgaard P, Parsons AN, Svoboda J, Virginia RA (1997) Open-top designs for manipulating field temperature in high-latitude ecosystems. Glob Change Biol 3:20-32

33. Mendes IC, Bandick AK, Dick RP, Bottomley PJ (1999) Microbial biomass and activities in soil aggregates affected by winter cover crops. Soil Sci Soc Am J 63(4):873-881

34. Meng C, Tian DS, Zeng H, Li ZL, Chen HYH, Niu SL (2020) Global meta-analysis on the responses of soil extracellular enzyme activities to warming. Sci Total Environ 705:9

35. Moorhead DL, Rinkes ZL, Sinsabaugh RL, Weintraub MN (2013) Dynamic relationships between microbial biomass, respiration, inorganic nutrients and enzyme activities: informing enzyme-based decomposition models. Front Microbiol 4:12

36. Nie M, Pendall E, Bell C, Gasch CK, Raut S, Tamang S, Wallenstein MD (2013) Positive climate feedbacks of soil microbial communities in a semi-arid grassland. Ecol Lett 16(2):234-241

37. Nie M, Pendall E, Bell C, Wallenstein MD (2014) Soil aggregate size distribution mediates microbial climate change feedbacks. Soil Biol Biochem 68:357-365

38. O'Neill BC, Oppenheimer M, Warren R, Hallegatte S, Kopp RE, Portner HO, Scholes R, Birkmann J, Foden W, Licker R, Mach KJ, Marbaix P, Mastrandrea MD, Price J, Takahashi K, van Ypersele JP, Yohe G (2017) IPCC reasons for concern regarding climate change risks. Nat Clim Chang 7(1):28-37

39. Post E, Forchhammer MC, Bret-Harte MS, Callaghan TV, Christensen TR, Elberling B, Fox AD, Gilg O, Hik DS, Hoye TT, Ims RA, Jeppesen E, Klein DR, Madsen J, McGuire AD, Rysgaard S, Schindler DE, Stirling I, Tamstorf MP, Tyler NJC, van der Wal R, Welker J, Wookey PA, Schmidt NM, Aastrup P (2009) Ecological Dynamics Across the Arctic Associated with Recent Climate Change. Science 325(5946):1355-1358

40. Pulleman MM, Marinissen JCY (2004) Physical protection of mineralizable C in aggregates from longterm pasture and arable soil. Geoderma 120(3-4):273-282

41. Qiao LL, Li YZ, Song YH, Zhai JY, Wu Y, Chen WJ, Liu GB, Xue S (2019) Effects of Vegetation Restoration on the Distribution of Nutrients, Glomalin-Related Soil Protein, and Enzyme Activity in Soil Aggregates on the Loess Plateau, China. Forests 10(9):18

42. Rinnan R, Michelsen A, Jonasson S (2008) Effects of litter addition and warming on soil carbon, nutrient pools and microbial communities in a subarctic heath ecosystem. Appl Soil Ecol 39(3):271-281

43. Rogelj J, Meinshausen M, Knutti R (2012) Global warming under old an new scenarios using IPCC climate sensitivity range estimates. Nat Clim Chang 2(4):248-253

44. Rui YC, Wang SP, Xu ZH, Wang YF, Chen CR, Zhou XQ, Kang XM, Lu SB, Hu YG, Lin QY, Luo CY (2011) Warming and grazing affect soil labile carbon and nitrogen pools differently in an alpine meadow of the Qinghai-Tibet Plateau in China. J Soils Sediments 11(6):903-914

45. Rui YC, Wang YF, Chen CR, Zhou XQ, Wang SP, Xu ZH, Duan JC, Kang XM, Lu SB, Luo CY (2012) Warming and grazing increase mineralization of organic $P$ in an alpine meadow ecosystem of Qinghai-Tibet Plateau, China. Plant Soil 357(1-2):73-87

46. Rustad LE, Campbell JL, Marion GM, Norby RJ, Mitchell MJ, Hartley AE, Cornelissen JHC, Gurevitch J, Gcte N (2001) A meta-analysis of the response of soil respiration, net nitrogen mineralization, and 
aboveground plant growth to experimental ecosystem warming. Oecologia 126(4):543-562

47. Sardans J, Penuelas J, Estiarte M (2008) Changes in soil enzymes related to C and N cycle and in soil C and $\mathrm{N}$ content under prolonged warming and drought in a Mediterranean shrubland. Appl Soil Ecol 39(2):223-235

48. Saxe H, Cannell MGR, Johnsen $\varnothing$, Ryan MG, Vourlitis GJNP (2001) Tree and forest functioning in response to global warming. New Phytologist. 2001, 149(3)

49. Schade AE, Levine AD (2003) Phosphatases in concert with kinases set the gain for signal transduction through the $\mathrm{T}$ cell receptor. Faseb J 17(7):C222-C222

50. Sinsabaugh RL, Hill BH, Shah JJF (2009) Ecoenzymatic stoichiometry of microbial organic nutrient acquisition in soil and sediment. Nature 462(7274):795-117

51. Sinsabaugh RL (2010) Phenol oxidase, peroxidase and organic matter dynamics of soil. Soil Biol Biochem 42(3):391-404

52. Six J, Bossuyt H, Degryze S, Denef K (2004) A history of research on the link between (micro)aggregates, soil biota, and soil organic matter dynamics. Soil Tillage Research 79(1):7-31

53. Six J, Carpentier A, van Kessel C, Merckx R, Harris D, Horwath WR, Luscher A (2001) Impact of elevated $\mathrm{CO} 2$ on soil organic matter dynamics as related to changes in aggregate turnover and residue quality. Plant Soil 234(1):27-36

54. Six J, Paustian K, Elliott ET, Combrink C (2000) Soil structure and organic matter: I. Distribution of aggregate-size classes and aggregate-associated carbon. Soil Sci Soc Am J 64(2):681-689

55. vanGestel M, Merckx R, Vlassak K (1996) Spatial distribution of microbial biomass in microaggregates of a silty-loam soil and the relation with the resistance of microorganisms to soil drying. Soil Biology Biochemistry 28(4-5):503-510

56. Wang JF, Wu QB (2013) Impact of experimental warming on soil temperature and moisture of the shallow active layer of wet meadows on the Qinghai-Tibet Plateau. Cold Reg Sci Tech 90-91:1-8

57. Wang RZ, Dorodnikov M, Yang S, Zhang YY, Filley TR, Turco RF, Zhang YG, Xu ZW, Li H, Jiang Y (2015) Responses of enzymatic activities within soil aggregates to 9-year nitrogen and water addition in a semiarid grassland. Soil Biology Biochemistry 81:159-167

58. Wang T, Yang YH, Ma WH (2008) The size, distribution and influencing factors of soil phosphorus pool in China. Acta Scientiarum Natyuralium Universitatis Pekinensis 44(6):945-945

59. Wang XX, Dong SK, Gao QZ, Zhou HK, Liu SL, Su XK, Li YY (2014) Effects of short-term and long-term warming on soil nutrients, microbial biomass and enzyme activities in an alpine meadow on the QinghaiTibet Plateau of China. Soil Biology Biochemistry 76:140-142

60. Wu Y, Chen W, Li Q, Guo Z, Li Y, Zhao Z, Zhai J, Liu G, Xue S (2020) Ecoenzymatic stoichiometry and nutrient limitation under a natural secondary succession of vegetation on the Loess Plateau, China. Land Degrad. Dev

61. Wang Y, Gao SQ, Li CL, Zhang JJ, Wang LC (2016) Effects of temperature on soil organic carbon fractions contents, aggregate stability and structural characteristics of humic substances in a Mollisol. J Soils Sediments 16(7):1849-1857 
62. Zhang CH, Willis CG, Klein JA, Ma Z, Li JY, Zhou HK, Zhao XQ (2017) Recovery of plant species diversity during long-term experimental warming of a species-rich alpine meadow community on the Qinghai-Tibet plateau. Biol Conserv 213:218-224

63. Zhang SX, Li Q, Lu Y, Zhang XP, Liang WJ (2013) Contributions of soil biota to C sequestration varied with aggregate fractions under different tillage systems. Soil Biology Biochemistry 62:147-156

64. Zhao XQ, Zhou XM (1999) Ecological basis of Alpine meadow ecosystem management in Tibet: Haibei Alpine Meadow Ecosystem Research Station. Ambio 28(8):642-647

65. Zhang XZ, Shen ZX, Fu G (2015) A meta-analysis of the effects of experimental warming on soil carbon and nitrogen dynamics on the Tibetan Plateau. Appl Soil Ecol 87:32-38

66. Zheng H, Liu Y, Chen Y, Zhang J, Li H, Wang L, Chen Q (2020) Short-term warming shifts microbial nutrient limitation without changing the bacterial community structure in an alpine timberline of the eastern Tibetan Plateau. Geoderma. 360

67. Zhou XQ, Chen CR, Wang YF, Xu ZH, Han HY, Li LH, Wan SQ (2013) Warming and increased precipitation have differential effects on soil extracellular enzyme activities in a temperate grassland. Sci Total Environ 444:552-558

68. Zhu GY, Shangguan ZP, Deng L (2017) Soil aggregate stability and aggregate-associated carbon and nitrogen in natural restoration grassland and Chinese red pine plantation on the Loess Plateau. Catena 149:253-260

\section{Figures}




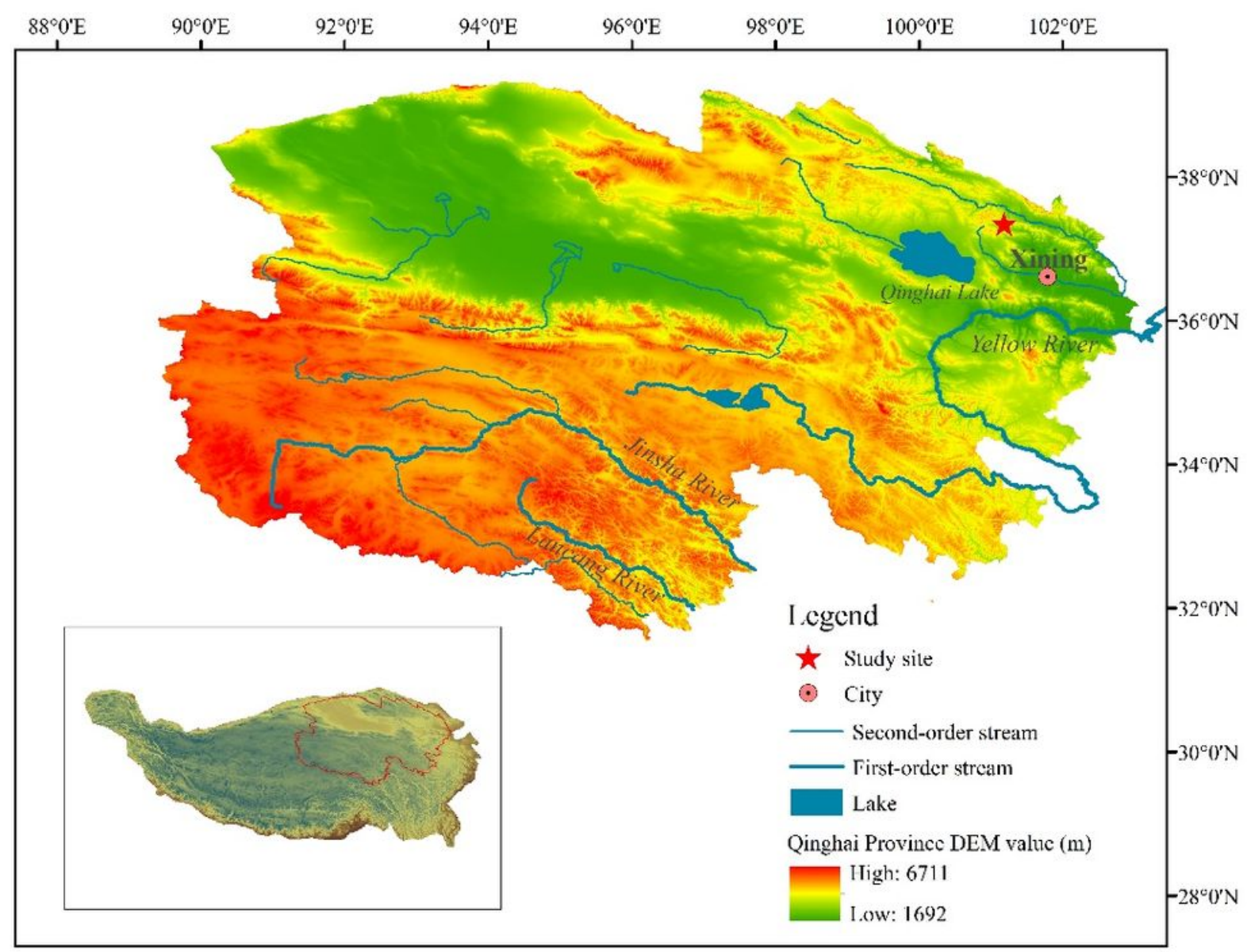

\section{Figure 1}

Location of the study site (Haibei Alpine Meadow Ecosystem Research Station) on the Qinghai-Tibet Plateau, China. DEM, digital elevation model 


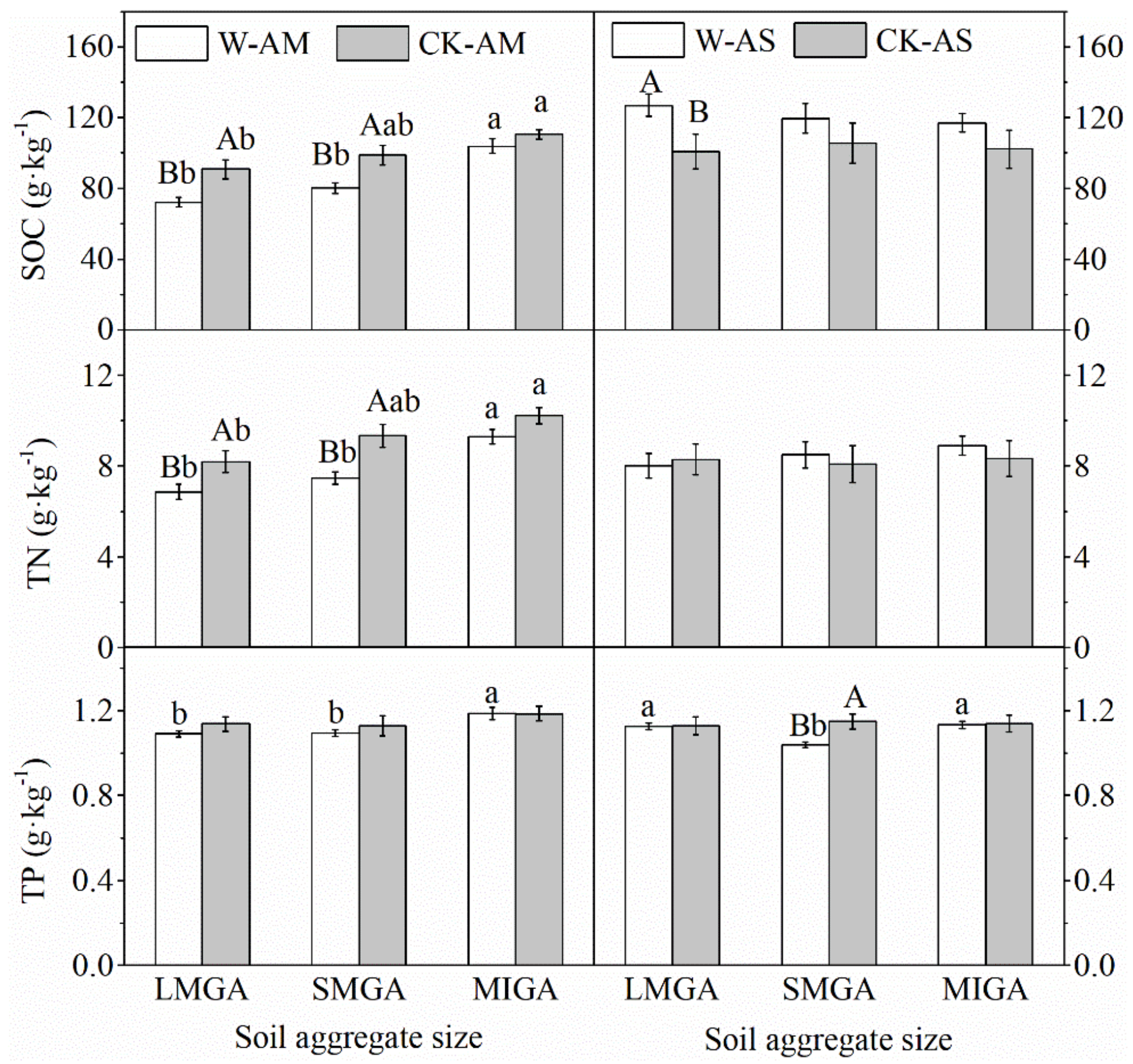

Figure 2

Changes in soil organic carbon (SOC), total nitrogen (TN), and total phosphorus (TP) among different soil aggregate size categories in the alpine meadow and shrubland under the long-term warming treatment. Note: W-AM: Warming-alpine meadow; CK-AM: Control-alpine meadow; W-AS: Warming-alpine shrubland; CK-AS: Control-alpine shrubland. MIGA: microaggregates, SMGA: small macroaggregates, LMGA: large macroaggregates. Error bars indicate standard errors. Different uppercase letters above the bars indicate significant differences in soil nutrients between different treatments in the same aggregate size category, and different lowercase letters indicate significant differences in soil nutrients under the same treatment among different aggregate size categories. The bars with the same letters are not significantly different at $p=0.05$, $n=6$. 


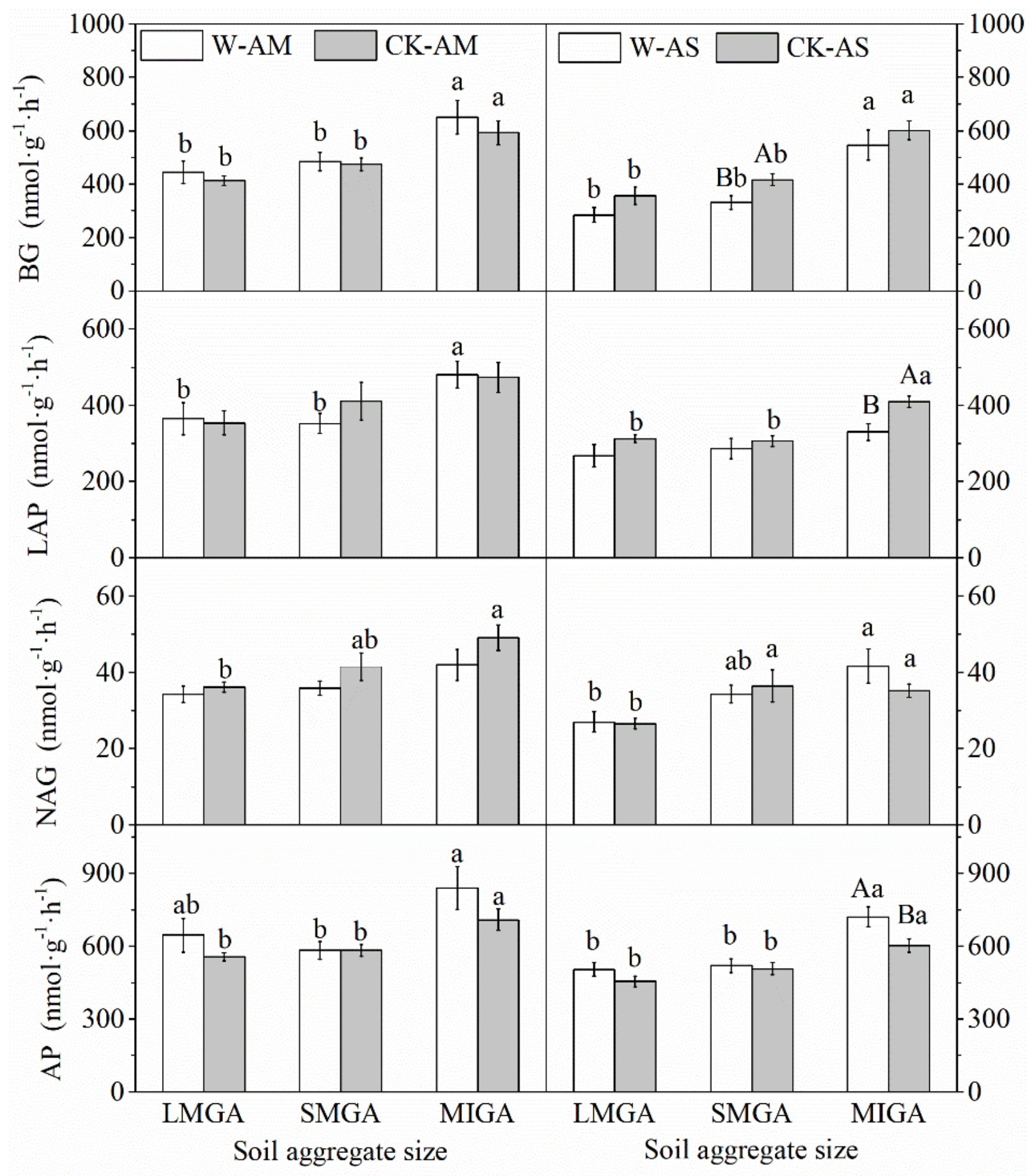

Figure 3

Changes in the activities of $\beta$-1,4-glucosidase (BG), leucine aminopeptidase (LAP), $\beta$-N-acetylglucosaminidase (NAG), and alkaline phosphatase (AP) among different aggregate size categories in the alpine meadow and shrubland under the long-term warming treatment. Note: W-AM: Warming-alpine meadow; CK-AM: Controlalpine meadow; W-AS: Warming-alpine shrubland; CK-AS: Control-alpine shrubland. MIGA: microaggregates, SMGA: small macroaggregates, LMGA: large macroaggregates. Error bars indicate standard errors. Different uppercase letters above the bars indicate significant differences in enzyme activities between different treatments in the same aggregate size category, and different lowercase letters indicate significant differences 
in enzyme activities under the same treatment among different aggregate size categories. The bars with the same letters are not significantly different at $p=0.05, n=6$.

\section{Supplementary Files}

This is a list of supplementary files associated with this preprint. Click to download.

- SupplementaryMaterial.docx 